\title{
ALMEIDA, Juliano Florczak de. Bom Jardim dos Santos: plantas, religiosidades populares e seus fluxos em Guarani das Missões (RS). Porto Alegre: Editora da UFRGS, 2016. $264 \mathrm{p}$.
}

Pedro Crepaldi Carlessi ${ }^{*}$

*Universidade de São Paulo - São Paulo, SP, Brasil

Pesquisador associado ao Centro de Estudos de Religiosidades

Contemporâneas e das Culturas Negras

pccarlessi@gmail.com 
Não só humanos participam da construção das religiões. Pelo contrário. Nessa seara diversos seres se enfeixam para compor a vida cotidiana e a manutenção de cultos e práticas diversas. Água benta, santinhos de calendário, figas, fitas, arrudas para o mau-olhado. Não é novo dizer que as coisas - deste e de outros mundos (para me referir a tudo aquilo que está para além do humano) - agenciam relações que dão cabo de enunciar os próprios predicativos da fé. Contudo, colocar-se a descrevê-las enquanto seres sociais e por aquilo que fazem tem se mostrado um exercício provocativo aos etnógrafos.

Atento às relações que humanos e não humanos estabelecem no campo religioso, em seu primeiro livro, Juliano Florczak de Almeida parte de um trabalho etnográfico realizado na cidade de Guarani das Missões, município localizado no noroeste do estado do Rio Grande do Sul, e analisa os fluxos de religiosidade que perpassam alguns vegetais encontrados nessa pequena cidade. O livro, fruto de uma dissertação de mestrado muito bem elaborada, apresenta os caminhos seguidos pelo autor durante o período em que se autodenomina como "jardineiro fiel" (p. 41).

A perspectiva etnográfica adotada nessa pesquisa merece ser mais bem apresentada. Uma vez em campo, a busca do autor não foi por religiosos que pudessem lhe dizer algo a respeito das plantas e seus compromissos com os santos. O autor descreve que sua tarefa foi "perseguir plantas e, de certa forma, receber os conselhos que estas oferecem aos [seus] interlocutores humanos" (p. 21). Para isso, metodologicamente parte daquilo que o antropólogo britânico Tim Ingold (2011) denomina por wayfaring perspective - "perspectiva do caminhante" -, um exercício translacional que foca no movimento e (inter)ação dos agentes em campo. Sua atenção está, a todo momento, na eminência de religiosidades que tecem os encontros entre plantas-homens-tempos-espaços-coisas na vida cotidiana da cidade de Guarani.

Para que isso fosse possível, coube ao etnógrafo desenvolver alguma intimidade com as plantas. Nos capítulos iniciais do livro, Juliano partilha alguns dos percursos e entraves desse processo. Fato interessante é que justamente esta abertura ao outro, digo, uma certa educação de sua atenção não só aos agenciamentos, mas também aos caprichos que caracterizam a vida das plantas, tornou o trabalho de campo do autor uma experiência autorreflexiva sobre os próprios caminhos de sua formação acadêmica. 
Ao aceitar o desafio de aprender com as plantas, sua etnografia permite, de antemão, reaver o caráter antropocêntrico que fundamentou, por muito tempo, as pesquisas em ciências sociais. Por esse viés, as plantas que o autor apresenta ficariam às margens dos possíveis significados culturais atribuídos a elas pelos citadinos que conheceu em campo. Contudo, a narrativa do autor se elabora por uma perspectiva bastante compromissada com as habilidades das próprias plantas na construção das religiosidades em Guarani das Missões.

Ao descrever as relações de mau-olhado vividas por Vinícius, um de seus entrevistados, o autor exemplifica: "A arruda não somente espanta, como todo bom amuleto, o mau-olhado. A desventura de Vinícius parece mostrar outra propriedade da planta: pode ser uma espécie de oráculo e dar testemunho do mundo" (p. 118). Esta breve passagem, que é esmiuçada teoricamente ao longo do livro e exemplificada também a partir de outras plantas, indica que, tratando-se da manutenção das práticas religiosas em Guarani das Missões, os vegetais não são meros objetos recobertos de significados culturais. Tampouco são seres que "vegetam", digo, cuja existência social é monótona. São eles mesmos construtores de realidades, às quais cabe alguma atenção dos humanos caso desejem livrar-se dos fluxos de mau agouro.

Se o compromisso do autor com as plantas serve aos antropólogos como mote a uma pesquisa para além-do-humano, igualmente, seus relatos dão fôlego às pesquisas em ciências biológicas que caminham rumo às "múltiplas botânicas" (p. 30). Sobretudo às chamadas "etnociências", que historicamente se dedicam às nuances culturais atribuídas às plantas ou às particularidades biológicas de plantas utilizadas por diferentes grupos humanos, o livro mostra-se pertinente, pois se elabora através de uma perspectiva de aliança entre $o$ binômio natureza-cultura. $\mathrm{O}$ autor foge da crítica cognitivista e opta pelo diálogo e mediação com essa específica forma de produção de conhecimento. Não no sentido de praticá-la, mas de sugerir um caminho de fuga ao reducionismo ora biológico, ora cultural. A esse respeito (e ainda sobre a arruda), conclui: "Se a arruda não acaba no verde pálido de suas pequenas folhas, tampouco invólucros das análises podem existir. Em razão disso, tento descrever as coisas não como redomas, mas como caminhos, seguindo a linha que perfazem" (p. 23). Advém dessa perspectiva a relevância da obra no espectro das literaturas em ciências sociais e biológicas interessadas na vida religiosa das plantas. 
No livro, o autor se preocupa em simetrizar os seres e fazeres que partilham o mesmo mundo-ambiente. Insere-se, dessa maneira, em um grupo de autores contemporâneos, dentro e fora da antropologia, que abandonam as premissas e concepções estabilizadas de corpos e paisagens para pensá-las enquanto instâncias permeáveis e definidas tão somente na relação que estabelecem. Para tanto, se o viés de uma certa "antropologia ecológica" aflora nessa etnografia, a influência do antropólogo britânico Tim Ingold é, certamente, uma influência de raízes profundas. Ao longo de sua análise, Juliano percorre conceitos elementares da teoria de Ingold (2011, 2012), como o de landscape, taskscape (p. 76) e skill (p. 141), e também vai ao encontro da revisita que Ingold (2008, 2010, 2015) faz à ideia de "cultura material" (p. 108), percepção e educação da atenção (p. 65).

Como uma imagem especular, a obra de Juliano reflete as influências da raiz ingoldiana. Partindo do mesmo caroço metafísico (entre tantos outros, o questionamento do antropocentrismo, do biocentrismo e a perseguição, em campo, por linhas de devir), o autor analisa não somente humanos e vegetais em Guarani das Missões, mas o fazer da vida (extra)ordinária desses seres em (inter)ação.

\section{Referências}

INGOLD, T. Pare, olhe, escute! Visão, audição e movimento humano. Ponto Urbe, n. 3, 2008.

INGOLD, T. Da transmissão de representações à educação da atenção. Educação, Porto Alegre, v. 33, n. 1, p. 6-25, jan./abr. 2010.

INGOLD, T. Being alive: essays on movement, knowledge and description. Abingdon: Routledge, 2011.

INGOLD, T. Trazendo as coisas de volta à vida: emaranhados criativos num mundo de materiais. Horizontes Antropológicos, Porto Alegre, ano 18, n. 37, p. 25-44, jan./jun. 2012.

INGOLD, T. O dédalo e o labirinto. caminhar, imaginar e educar a atenção. Horizontes Antropológicos, Porto Alegre, ano 21, n. 44, p. 21-36, jul./dez. 2015. 